Joanna $R A K^{*}$

\title{
POLICING ANTI-GOVERNMENT PROTESTS DURING THE CORONAVIRUS CRISIS IN POLAND: BETWEEN ESCALATED FORCE AND NEGOTIATED MANAGEMENT $* *$
}

\begin{abstract}
This research aims to give insight into the processes of public interaction between the police and antigovernment protesters during the Coronavirus Crisis in Poland by evaluating crowd control mechanisms. It addresses the research question: where does the model of anti-government protest policing developed by the Polish Police during the Covid-19 pandemic lie on a continuum of antinomic ideal types of escalated force and negotiated management? The research is embedded in studies on protest policing and draws on an intertextual qualitative analysis of police statements and media news. It shows that the policing of protests was closer to escalated force. However, a hybrid model was involved that combined elements of coercion and negotiation. In terms of protecting the right to freedom of peaceful assembly and police tolerance for community disruption, this particular form of policing is close to escalated force. Still, the communication between the police and the assembly participants, the extent and manner of the arrests closely mirrored both models. One dimension, the extent and nature of the force used, indicated negotiated management.
\end{abstract}

Keywords: protest policing, contention, contentious politics, de-democratisation, Coronavirus Crisis, Poland

\section{Introduction}

Since winning the state's presidency and gaining a majority in the Sejm in 2015, the conservative Law and Justice party (Prawo i Sprawiedliwośc) has started to lay the foundations for an anti-democratic turn in Poland. Under the

* Joanna Rak, PhD, Assocciate Professor, Faculty of Political Science and Journalism, Adam Mickiewicz University, Poznań, Poland.

** This work was supported by the National Science Centre, Poland under Grant 2018/31/B/ HS5/01410 [Contentious Politics and Neo-Militant Democracy].

DOI: 10.51936/tip.58.specialissue.598-615 
banner of "good change" (dobra zmiana), the ruling party has dismantled the existing checks and balances by subordinating the Constitutional Tribunal, courts, and judges to the government, transforming the public media into partisan state media, limiting the freedom of assembly, privacy, and the press (Fomina and Kucharczyk, 2016: 58). These changes triggered a wave of antigovernment mobilisation, the establishment of civil movements like the Committee for the Defence of Democracy (Komitet Obrony Demokracji) or the Citizens of Poland (Obywatele RP), and mass protests. The party immediately labelled those who challenge it enemies of the state and Polish people.

In March 2020, despite lacking any authority to limit the human and political rights that stem from the Constitution of the Republic of Poland, the government imposed safety rules which officially restricted the freedom of assembly, religion, and movement so as to prevent the spread of Covid19. These limitations fell into the pattern of the state-driven weakening and elimination of political institutions that sustain the democratic framework (Daly and Jones, 2020: 509). However, the criminalisation of participation in protests, great financial penalties for defying the ban on assembly (EUR $2,200-6,650)$ and, finally, the state media's wholesale demonisation of protesters could not stop challengers from taking to the streets.

In Poland, constitutional regulations (Article 57) and the 2015 Law on Assemblies guarantee the freedom to organise and participate in peaceful assemblies. The latter repealed the 1990 Law on Assemblies and brought in new regulations. First and foremost, Article 2 of the 2015 Law on Assemblies does not apply to assemblies held by public authorities. For the first time, this restriction was used during the pandemic, when the government unconstitutionally banned the organisation of public gatherings. Accordingly, the Covid-19-induced ban did not apply to events that met the criteria for a public gathering but were held by public authorities. This simultaneously meant anti-government protests could not continue during the pandemic, while the election campaigns of candidates opposing the incumbent president could not be run. Moreover, the 2016 amendment introduced a new category of cyclical assemblies and prioritised them over all others. It privileged the monthly Smoleńsk commemorations (Miesięcznice Smoleńskie), a cyclical event Law and Justice organised to commemorate the victims, including President Lech Kaczyński and his wife, of the tragic Smoleńsk plane crash in 2010. The amendment thus essentially deprived opposition members of their right to assemble and protest. Finally, the 2015 Law on Assemblies requires that the municipal authorities of any assembly be notified no sooner than 30 days and no later than 6 days before it begins (Article 7). While the pro-government gatherings held by public authorities could occur during the pandemic without pre-declaration and permission, their anti-government counterparts were not officially allowed. 
This research aims to give insight into the processes of public interaction between police and anti-government protesters during the Coronavirus Crisis in Poland by evaluating the mechanisms of crowd control. It considers the research question: where does the model of anti-government protest policing developed by the Polish Police during the Covid-19 pandemic lie on a continuum of antinomic ideal types of escalated force and negotiated management? The scope of the evaluation focuses on forms of assembly policing as responses of the state to protests and assemblies. Serving as gatekeepers to the judicial system, the police are an integral element of state repression systems (della Porta, 1995: 3; Mansley, 2014: 56). This research argues that the policing of anti-government protests developed by the Polish Police during the Covid-19 pandemic has been closer to the ideal type of escalated force. This study contributes empirically to our understanding of state-driven attempts to control the state's opponents. Analysis of the objectives and methods used by the police reveals the extent to which it is subordinated to the state.

\section{Literature Review and Theoretical Framework}

The social control of public protests by police is a useful indicator of state authorities' general approach to controlling particular dissident groups (Earl, Soule and McCarthy, 2003: 582). Protest policing styles draw upon the differentiation between tactics that range from coercion to negotiation. The criterion for their division is the degree to which protesters are to be engaged as legitimate participants in the socio-political process (Wang, Joosse and Cho, 2020: 1524). Pending the anti-austerity wave of protests in European states, researchers point out specific styles of protest policing. This development entails moving away from the traditional escalated force model towards negotiated management (cf. Whelan and Molnar, 2019: 85; Stott and Radburn, 2020: 77). With the escalated force model, the police give low priority to peaceful assembly rights. Communication between the police and the protesters is reduced to a bare minimum, and coercive or even illegal protest policing methods are frequent. In the negotiated management model, the police respect the political right to peaceful assembly, perceive the communication between the police and the protesters as underpinning the peaceful conduct of protest, and avoid coercive means (della Porta and Reiter, 2006: 13). The anti-austerity-driven mobilisation led to the popularisation of hybrid types of protest policing, which combine the features of both models but vary in their configurations (Rak, 2018: 96).

Jennifer Earl, Sarah A. Soule and John D. McCarthy delve into the theoretical frameworks of protest policing to discuss the major features of specific methods (Earl, Soule and McCarthy, 2003: 583). The threat-based approach 
underlines that the bigger the threat to ruling authorities, the more severe the protest policing model expected. Those groups using noninstitutional, confrontational tactics, pursuing revolutionary, counter-cultural or radical goals, successfully attracting mass media, and mobilising public opinion in their favour are deemed threatening (Earl, Soule and McCarthy, 2003: 583; Wisler and Giugni, 1999: 171). At the same time, larger numbers of mobilised individuals are viewed as posing a greater danger (Davenport, 2000: 4). According to the weakness-based approach, ruling authorities use a more repressive protest policing model against groups they assume will collapse under pressure. Weak groups display their relative inability to react to undue or serious uses of force (Earl, Soule and McCarthy, 2003: 583-584; Wisler and Giugni, 1999: 171). These models focus on the impact of protest characteristics on coercion as mediated by the state authorities' perception of threat (Wisler and Giugni, 1999: 172).

Donatella della Porta and Herbert Reiter advance an approach that allows researchers to see differences between protest policing styles across democratic systems (Wisler and Giugni, 1999: 172). They formulate a dual typology to describe distinctions between the styles of protest policing according to nine indicators. These indicators' antinomic extreme values typify the models of escalated force and negotiated management (della Porta and Reiter, 1998: 7). The indicators and their antinomic extreme values are as follows: the degree of force used by police (brutal/soft), the number of prohibited behaviours (repressive/tolerant), the number of repressed groups (diffused/selective), police respect for the law (illegal/legal), the timing of law enforcement (reactive/preventive or pre-emptive), the degree of communication with demonstrators (confrontational/consensual), the degree of "adaptability" understood as the capacity to adjust to emerging situations (rigid/flexible), the degree of formalisation of the rules of the game (infor$\mathrm{mal} /$ formal), and the degree of "preparation" (artisanal or improvised/professional) (della Porta and Reiter, 1998: 4). The antinomic extreme values grouped into two ideal types constitute models of escalated force and negotiated management. These models establish a continuum with two extreme apparent ends on which various forms of policing might be placed. The more salient features a particular mode of enforcement displays, the closer it moves to one end or the other on the continuum.

Even though this theoretical framework significantly contributes to our understanding of critical differences in state responses to protest, its components lack precise definitions, which impedes measurement of protest policing. As della Porta and Reiter argue, use of force by law enforcement places policing between "brutal" and "soft" values (della Porta and Reiter, 1998: 4; della Porta, 1995: 7, 27). Yet, the differences between these values remain unclear, thereby hindering clear distinctions, such as using threats 
(e.g. riot formation) (Terrill, 2005: 107). Moreover, della Porta and Reiter consider the number of groups repressed by the police as a quantitative indicator but assign qualitative values of diffusion and selectiveness (della Porta and Reiter, 1998: 4). Although neither the indicator nor the values are specified, the latter shed light on the potential reluctance of assembly participants. Random and mass arrests are specific to the escalated force model. In turn, under the negotiated management model, law enforcement will detain only those protesters who break the law or put human lives or property at risk.

There is also a caveat about the timing of police intervention. On one hand, as della Porta and Reiter assume, preventive action is characteristic of negotiated management, whereas reactive action typifies escalated force (della Porta and Reiter, 1998: 4). On the other hand, Clark McPhail and John D. McCarthy emphasise that pre-emptive actions may consist of raids on activists' residences and headquarters, the confiscation of resources (e.g. banners) and detention of rank-and-file activists (McPhail and McCarthy, 2005: 4). These two aspects of timing refer to distinct phases of police intervention and require separate conceptual approaches (Walker, 2020: 120).

Della Porta and Reiter define the degree of "preparation" as training. Its extreme values are improvised and professional action (della Porta and Reiter, 1998: 4). Nevertheless, the authors avoid clarifying what is meant by "improvised" and "professional" action. Further, the indicator and the values might relate to entirely different phenomena. Well-trained police officers may improvise successfully when some procedures are underdeveloped. Professionalism may involve improvisation in unprecedented situations and result in efficient protest policing. Finally, professionalism is an antinomic feature of unprofessionalism rather than improvisation, provided that professionalism is understood as the careful attention and skills that trained officers are expected to possess.

A modified framework to differentiate between escalated force and negotiated management was developed by Clark McPhail, David Schweingruber and John D. McCarthy. The authors identify five distinct features of protestpolicing styles. They refer to them as dimensions of protest policing because each is a continuum along which one can place any example of law enforcement action during protests. These dimensions include the willingness of law enforcement to protect the right to assembly (also called the extent of police concern with the First Amendment rights of protesters), the extent of police tolerance for community disruption, the nature of the communication between the police and assembly participants, the extent and manner of arrests as a method of managing assembly participants, and the extent and manner of using force instead of or in conjunction with arrests to control assembly participants (McPhail, Schweingruber and McCarthy, 1998: 51). 
The first dimension of McPhail, Schweingruber and McCarthy's theoretical framework draws on protection of the political right to peaceful assembly. In the escalated force model, law enforcement deems some assemblies illegitimate and acts to repress them. The equal treatment of citizens takes a back step to compliance with the will of the political elites (Earl and Soule, 2006: 145). In the negotiated management model, the police recognise the universality of the right to peaceful assembly and tolerate protests. Officers aim to protect human rights, life and property (McPhail, Schweingruber and McCarthy, 1998: 51).

Tolerance for community disruption is the second indicator. Under the escalated force model, only the familiar and non-disruptive forms of protest are tolerated. With the negotiated management style, the police accept disruption as a by-product of assemblies. The police do not attempt to prevent demonstrations but may seek to curb or reduce disruptions (McPhail, Schweingruber and McCarthy, 1998: 52).

The third dimension covers the communication between the police and the assembly participants. It is minimal under the escalated force model. Exceptions are undercover police infiltration and acting as agent provocateurs. The police avoid conferring with assembly organisers before or during events. Law enforcement adamantly refuses to give up any assembly control to the protesters. Under the negotiated management style, the police initiate and maintain extensive interaction with protesters via permit application, negotiation, granting, and protection. In contrast to the escalated force model, time, place, manner restrictions, conflicts over these restrictions, organisational issues such as transportation, restroom facilities, and first aid are negotiated (McPhail, Schweingruber and McCarthy, 1998: 52-53).

The extent and manner of arrests determine the fourth dimension. In the escalated force model, arrests are widespread and may even be carried out when no law is broken. Under the negotiated management model, arrests are used as a last-resort tactic and only against those assembly participants who violate the law. Police do not arrest violators immediately but repeatedly warn them they are breaking the law. Necessary arrests are carried out with proper documentation and in an orderly way to avoid injuring assembly participants (McPhail, Schweingruber and McCarthy, 1998: 53).

The last dimension is the extent and manner of force. In the escalated force model, force is a standard way of dealing with assemblies. Officers confront protesters with a noticeable show of force. The level of force increases gradually unless the assembly participants obey police instructions and limit their activities. The use of force includes riot control techniques, tear gas, batons, fire hoses, water cannons, electric cattle prods, riot formations, dogs, and horses. Those means displace arrests (McPhail, Schweingruber 
and McCarthy, 1998: 53-54). However, escalated force may also entail the police allowing counter-protesters to use force against the protesters, all under the eye of law enforcement officers. In the negotiated management model, police only use minimum necessary force to fulfil their duties, especially protecting people and property, and detaining lawbreakers. Police officers try to avoid the use of force by cordoning off the assembly area and negotiating with assembly participants (McPhail, Schweingruber and McCarthy, 1998: 53-54). McPhail, Schweingruber and McCarthy's model provides theoretical grounding and underlies the thematic analysis of data, discussed along with research methods.

\section{Research Methods and Materials}

We now take a look at the model of policing developed by the Polish government during the Covid-19 pandemic and see where it lies on the abovementioned continuum. To address this research question, I carried out an intertextual qualitative analysis of police statements and news released during the first wave of the pandemic, from detection of the coronavirus in Poland up until the lockdown measures were lifted (4 March-31 May, 2020).

604 To achieve validation, convergence, corroboration, and representativeness for protest policing characteristics, the corpus of sources contains entries from the Polish Police official website and tweets as well as news distributed by popular Polish media (Onet.pl, TVN24, RMF FM, Rzeczpospolita). The data are also triangulated with datasets of the Global Database of Events, Language, and the Tone Project database (GDELT Project), namely, GDELT Event Exporter and the GDELT Event Database. Source triangulation serves to eschew the favouring of either state or commercial media narration and creates a reliable database for protest policing.

The first set of materials reveals the state-controlled police perspective. It includes entries from the Warsaw Police Headquarters official website because this entity policed most of the major anti-government protests in the capital city. The website was a primary means of informing the public regarding police activities. The set contains the Warsaw police's official and verified Twitter profile used to communicate with protest participants and comment on protest policing on an ongoing basis. Due to the lack of references to public assemblies in the posts and videos on the police's YouTube channel and Facebook and Instagram accounts, these social media are excluded from the corpus of sources.

Entries on the police official website and tweets were manually searched with respect to the co-occurrence of the following search phrases: (1) police and/or police officers and/or officers; and (2) assembly and/or gathering and/or protest and/or demonstration and/or manifestation and/or rally 
and/or strike and/or riot and/or social unrest and/or participants of these contentious collective gatherings. By applying the above criteria, 3 entries and 79 tweets were detected in the corpus.

"The most opinion-forming media in Poland" reports published monthly since 2003 by the Institute of Media Monitoring (IMM) underlay the criteria for selecting contrasting perspectives. The IMM searches for, analyses, and archives content appearing in the mass media (Internet and social media, press, radio, television). Its reports provide information on the number of media quotes appearing in other media, excluding news agencies and reprints. A constantly high number of citations is one element that increases the credibility and opinion-forming of a given medium. According to the IMM, four media reached more than 3,000 citations a month between March and May 2020, outperforming other titles that had about 2,000 or fewer citations. In March, the most influential of these media were: the web portal Onet.pl (4,304 citations), the television station TVN24 (3,145), the radio station RMF FM (3,116) (IMM, 2020a); in April: Onet.pl (5,381), RMF FM (4,318), TVN24 (4,003), the daily newspaper Rzeczpospolita (3,426) (IMM, 2020b); in May: Onet.pl (5,523), RMF FM (4,716), Rzeczpospolita (3,415), and TVN 24 (3,400) (IMM, 2020c).

The archives of Onet.pl, TVN24, RMF FM, and Rzeczpospolita were also manually searched for the co-occurrence of the search phrases outlined above. The corpus of sources includes the archives of the most influential media in respective months. These criteria led to the following sources being selected: Onet.pl - in March - 6 news, April - 43, and May - 124; TVN24 - in March - 4, April - 32, and May - 98, RMF FM - in March - 9, April - 48, and May - 168, Rzeczpospolita - in April - 25 and May - 60.

The GDELT Project is a real-time network diagram and CAMEO-coded data set of a global society that has been combining online records of social and political events since 1979. Published in 65 languages (e.g. BBC Monitoring, New York Times), these records derive from various news outlets around the globe. The project transforms them into a computable format and is automatically updated every 15 minutes. The GDELT Event collection contains records of details of political events from 1 January 1979 until the present, coded across 59 variables (della Porta, 2016). The GDELT dataset draws upon PERL, R, and Google BigQuery, which provides a broad range of news from highly diversified Polish, national and international media materials (Bodas-Sagi and Labeaga, 2016: 38; Hopp et al., 2019: 13).

The search criteria used to generate the dataset from GDELT EVENT Exporter and Database were: Start Date $=04 / 03 / 2020$; End Date $=$ $31 / 05 / 2020$ (the first wave of the coronavirus pandemic in Poland); Actor1 Country: Poland (location of event: Poland); Event Code: 14 (the type of event: protest); Event Country: Poland (type and state affiliation of initiator 
of the action: Poland); Weighting: NUMEVENTS (an aggregation of the CAMEOevent codes into four categories ranging from Verbal Cooperation to Material Cooperation, Verbal Conflict, and Material Conflict). The news set covers 1,036 items (news) from the Exporter and 387 from the Database.

In terms of validity, there is no discrepancy between the data from the different sources included in the corpus, even though the bulk of evidence comes from the media. The analysis rests on the assumption that the sources are equivalent vessels for information on protest policing details. The data gathered across the datasets are sufficient and necessary to identify consistent themes and patterns across protest policing dimensions and to discover outliers and themes unique to individual datasets.

Cross-media source analysis draws on the iterative process of skimming, examination and interpretation. It involves the techniques of content analysis and thematic analysis (Bowen, 2009: 31-32). The former commences by identifying text passages that contain direct references to police respect for and protection of the right to assembly, police tolerance for community disruption, communication between the police and assembly participants, arrests, and the use of force by the police. Subsequently, information on protest policing is organised into categories related to the research question and 606 embedded in the theoretical framework: the protection of freedom of assembly (selective/stated top priority for all), tolerance for community disruption (low/high tolerance), communication between the police and assembly participants (low/high), the extent and manner of arrests (frequent arrest/last resort), the extent and manner of the force used (great extent/last resort).

The thematic analysis entailed re-reading and reviewing selected data and defining themes pertinent to specific dimensions of protest policing styles. The analysis began with a categorisation based on the data's characteristics (Bowen, 2009: 31-32). The coding of the documents' content is based on five groups of search terms derived from McPhail, Schweingruber and McCarthy's modified theoretical framework.

By drawing on an inductive approach, the constant comparative method bolstered the data analysis. This approach helped determine the theoretical aspects of protest policing. A back-and-forth interplay with the data facilitated an examination of the codes and concepts. The data were mutually collated while codes were utilised to organise ideas and spot clustering concepts. When certain documentary evidence is not corroboratory but contradictory, it is necessary to investigate further to set the most plausible values of the protest-policing dimensions. The convergence of information from different sources increases confidence in the credibility of findings. This verification procedure minimises the likelihood of biases that can occur in a single case study. It also triangulates data to guarantee a convergence of evidence that assures credibility (Bowen, 2009: 28, 30, 37). 


\section{Research results}

The first dimension of the analysis relates to police obligations to respect and protect the freedom of assembly. Since 2015, the law on public assemblies has not applied to assemblies held by state authorities. This created a double standard for political activity. As cross-media analysis shows, the possibility of exercising the right to freedom of peaceful assembly was neither fairly distributed nor universally protected by the Polish Police during the pandemic. Rather than being influenced by fear of the pandemic's spread, the policing of assemblies was chiefly shaped by purely political aims of the state. On 10 April 2020, Law and Justice held a public assembly to commemorate the Smoleńsk plane crash, which had claimed the lives of many important political figures. Those participating in the pro-government assembly had acted in defiance of the complete ban on public assemblies first introduced by a Minister of Health decree on 31 March and followed by later decisions of the Council of Ministers. In addition, they had contravened the sanitary regulations, including the obligation to keep a distance of $2 \mathrm{~m}$ between persons and to cover their faces. Journalists documented that the police had in no way punished or criminalised these pro-government assembly participants. Similarly, the incumbent president's meetings with the electorate were neither controlled by the police nor considered illegal.

Between March and May, those opposed to the restrictions continued to protest. Cross-media analysis shows that activists who opposed the infringing of the Polish Constitution and undermining of the judiciary's independence were punished with EUR 2,200 fines for alleged breaches of the sanitary regulations. On 6 May, political activists and artists protested against postal voting during the presidential election to be held on May 10. The election was set to be held at a time when only the candidate of the incumbent party had the possibility of campaigning. Police checked the IDs of those who brought a 14-m-wide banner bearing the slogan "To Live, Not to Die" next to the Sejm building and ordered two of them to pay a fine of EUR 2,200 to the Chief Sanitary Inspectorate (Sanepid) for having broken the sanitary regulations. However, the inspectorate investigated the case and cancelled the fines after confirming that the protesters had kept a 2-m distance from others and had covered their faces. On 8-9, 16 and 23 May, police imposed a EUR 2,200 fine on numerous participants of the Strike of Business Owners, a wave of protests against the government's lack of support for small enterprises during the pandemic. Police also levied fines on the assembly participants in front of the state radio station (Trójka) on 22 May. Activists opposed censoring Kazik's "Your Pain is Better than Mine", a song which was critical of the leader of Law and Justice, Jarosław Kaczyński, and other party officials who had visited their family graves while the graveyards were closed to 
ordinary people. In contrast to the pro-government assembly, participation in the anti-government protests was penalised with heavy fines.

The second difference in the policing of the pro- and anti-government assemblies was discursive delegitimisation of the latter. The police accused those challenging the government's position of creating state-wide chaos (Policja, 2020b; 2020c). They presented the activists as criminals who were purposefully spreading the virus and thereby putting human lives and health at risk (Policja, 2020d). The second alleged motivation for participation was to attack, hurt and prevent officers from performing their official duties (Policja, 2020e). Meanwhile, law enforcement officials and spokespeople discursively legitimised the pro-government participation by pointing to the unique nature of the Smolensk annual commemoration. According to the police, it did constitute an assembly within the meaning of the law. People taking part in the ceremony were acting in line with their occupation, just like journalists doing reporting work (Policja, 2020a).

In terms of protecting the right to freedom of peaceful assembly, the Polish Police developed a style of protest policing that may be described as closer to escalated force than to negotiated management. According to the repressive model's characteristics, the police considered anti-government 608 assemblies to be illegitimate and repressed those participating in them with considerable fines and socially hurtful delegitimisation. The unprecedented pandemic situation, the double political and legal standards, interest groups' low level of institutionalisation, and the insufficient legal aid for repressed individuals made the protesters a weak opponent (Earl, Soule and McCarthy, 2003: 583-584; Wisler and Giugni, 1999: 171). Police obligations to respect and protect the freedom of assembly of the anti-government groups which, according to the ruling authorities, would buckle under pressure, were limited (Wisler and Giugni, 1999: 171). The unequal treatment of the pro- and anti-government assemblies revealed political bias. The police were enforcing orders that served the ruling party, not the public interest. Thereby, the interest of the ruling party had replaced equal treatment, as is typical of escalated force (Earl and Soule, 2006: 145).

The second dimension is the extent of police tolerance for community disruption. Following the beginning of the pandemic, the police had maintained that participation in anti-government assemblies was an absolute breach of all safety rules and the applicable legal order. Protesters were violating many restrictions introduced to limit the coronavirus' spread. Although information about the ban on gatherings was widely available and understandable, protesters disregarded it. Their irresponsible behaviour prompted the response of police officers, who "were needed elsewhere" (Policja, 2020f; 2020g; 2020h). Police could not perform their routine activities of helping citizens and perceived the assemblies as a source of disorder. 
Moreover, the police criticised the Strike of Business Owners for breaking the traffic rules and causing heavy traffic in the capital city (Policja, 2020i). The anti-government demonstrations were described as nuisance impeding the life of citizens.

To sum up, police tolerance for community disruption was low. The protest policing model was close to escalated force because taking to the streets was neither tolerated nor contextualised as an exercise of political rights. The police treated the anti-government, but not the pro-government, public assemblies as the source of community disruption. Only the former had prevented the police from performing their duties. Although law enforcement was engaged in policing of the commemoration of the Smoleńsk plane crash, it did not condemn this event as disruptive. Typical of the escalated force model, the police failed to accept the disruption as a by-product of an assembly and designated it with having the primary purpose of a political activity. Instead of limiting the disruption caused by assemblies, law enforcement tried to prevent demonstrations by discouraging political opponents from joining protests, persuading them to go home, and delegitimising them as criminals breaking the law. Measures to dissuade activists from protesting were orders, fines and detentions. They prevented protesters from attracting the mass media and mobilising public opinion in their favour (Wisler and Giugni, 1999: 171).

The third dimension under scrutiny is the nature of the communication between the police and the assembly participants. The statements issued by officers authorised to represent the police show they treated the communication as a one-sided process, typical for the escalated force model. However, the establishing of relations between the police and the protesters had the characteristics of both protest policing styles. The police emphasised that they "spoke to the people gathered", made announcements, and launched the Police Anti-Conflict Team (Policja, 2020j). On one hand, the anti-conflict initiative aimed to prevent any escalation of the conflict between the police and activists yet, on the other, the group was mainly focused on resolving the crisis and not working out solutions that would allow protesters to make claims in the public sphere. Further, those participating in the anti-government assemblies were not shown as partners for talks or negotiations. Treating protesters as a group of disobedient criminals and not equal participants in the political process was a discursive designation of public roles by the police. The police expected the activists to follow orders and give up their right to freedom of peaceful assembly.

While the police insisted they had been willing to communicate with the protesters, several factors undermine the credibility of this claim. Crossmedia analysis exposed glaring contradictions between the police version of events and other versions. The police did not seek to verify any other 
perspectives and maintained their position until nationwide media published contradictory evidence. For instance, the police had disavowed the use of batons against protesters up until Gazeta Wyborcza journalists published certain recordings. The police then argued that the officer who used force had not reported the use of direct coercion measures to their superiors and was subsequently fired (Policja, 2020k). Moreover, in the face of other recordings also disseminated by activists, the police remained insistent. The police stated that Senator Jacek Bury had entered a police car and ignored police requests to exit it. Another protest participant, a Gazeta Wyborcza journalist Paweł Rutkiewicz, allegedly did not notify officers about his press credentials. The police accused activists who presented contradictory evidence of acting in bad faith. Whereas videos recorded from the front of the car show police officers shoving the senator through the door, the police themselves disseminated a video recorded from behind the backs of other activists to prove that the senator had entered the squad car on his own. In the latter recording, the officers' view was blocked by the activists. The police treated the backlash as unfounded and based on false witness testimony. Finally, some police sources said that the senator arrested himself, while others maintained that the police did not know the detainee was a senator (Policja, 20201; 2020m).

To conclude, the communication between the police and the assembly participants places the protest policing in the middle of the escalated force and negotiated management continuum. The policing of the anti-government assemblies had essential features of both models. The media did not report instances of undercover police infiltration during the anti-government assemblies. Further, officers sporadically initiated and maintained interaction with assembly participants via the protection process. They took initiatives to deescalate conflicts and informed about the official activities undertaken and their legal basis. However, not unlike in the escalated force model, the police did not engage in communication with the assembly organisers before or during events and refused to cede any control over the assemblies. Officers were not oriented to negotiating positions and actions but preferred to issue orders. Discrepancies between the police's and activists' versions of events and the overt disregard of inconvenient facts prevented communication based on trust.

The fourth dimension of the analysis constitutes the extent and manner of arrests as a method of managing the assembly participants. By drawing on new regulations, the police acted in the interest of the ruling party. A wave of mass arrests swept through anti-government assemblies. Assembly participants knew the legal basis for the law enforcement services' actions and were aware of restraints from the beginning of mobilisation. Moreover, during the assemblies, police repeatedly reminded protesters about the 
existing ban on assemblies, appealed for lawful behaviour, and informed the public that it would use force if necessary. Failure to follow police orders led to numerous detentions. The number of arrests was high, over onethird of all participants. During one day of the Strike of Business Owners, being attended by approximately 1,000 people, 380 of them were detained (Makarewicz and Balinowski, 2020). Many detentions were preventive, as the police openly declared (Policja, 20201), meaning those detained were released after activities at the police station had been performed. The materials collected by journalists show that the mass detentions were often random.

The extent and manner of arrests place law enforcement in the middle of the continuum. Arrests were made even when no specific law was being broken. Cross-media analysis reveals that some people were detained even if their actions did not put human lives, health or property at risk. Nevertheless, police had repeatedly informed assembly participants that they were breaking the law. Warnings of this sort are characteristic of negotiated management.

The fifth dimension covers the extent and manner of the force used. Cross-media analysis shows how activists clashed with police officers during anti-government assemblies. The latter used force and justified their violent actions by stating that the direct coercion measures chosen were appropriate to the situation and danger posed by protesters. In general, in accordance with negotiated management, officers neither misused force nor provoked clashes. Yet, while calling for dispersal, officers restlessly swung their assault batons and shields, which might have been considered provocative. They used passive physical violence by exposing riot gear, hand-held disabling gas throwers, backpack tear gas dispensers, and batons.

As journalist recordings reveal, although police attempted to disperse the crowd during the Strike of Business Owners, they could not do so and applied containment instead (also known as kettling or corralling). This police tactic serves to control and isolate large crowds during public assemblies. Police officers form large cordons and move to contain people within a limited area. The tactic is controversial because bystanders may be contained by mistake; those contained cannot leave the area without permission and are cut off from food, water and sanitation. Nevertheless, the containment was a relatively non-intrusive and proved to be an efficient way to protect the public from violence.

The extent and manner of using force locate protest policing close to negotiated management. In contrast to the escalated force model, the force used was not a standard way of dealing with gatherings. Officers did not confront the assembly participants with a noticeable show of force. Even though the use of force included riot-control techniques, namely tear gas, 
batons, and riot formations, these means did not displace arrests. Moreover, according to the media, the police refused to prompt or allow activists to engage in fighting and rioting. Just like in the negotiated management model, police used only the minimum force necessary to fulfil their duties insofar as protecting persons, property and arresting lawbreakers. Police officers attempted to avoid using force by cordoning off the assembly area.

\section{Conclusion}

To sum up, the policing of anti-government protests developed by the Polish Police during the Covid-19 pandemic was closer to the ideal antinomic type of escalated force. However, it was a hybrid model that combined elements of coercion and negotiation. The Polish hybrid model of protest policing falls into the category social control of public protest typical of the anti-austerity mobilisation in Europe. While it reflects a post-crisis tendency to move away from the traditional escalated force model towards negotiated management, it also corresponds with the Polish government's politics after 2015 in that it seeks to limit the ability of its opponents to participate in both the public sphere and political discourse. The dominance of

$\mathbf{6 1 2}$ elements of the repressive model reveals the severity of these trends during the Coronavirus Crisis.

The characteristics of the Polish model indicate the state authorities' general programme of controlling particular dissident groups. As the characteristics of the model show, law enforcement wholly complied with the government and acted in the interest of the ruling party. The crisis was a particular time requiring the police to act on the basis of double legal and political standards. On one hand, provisions of the Constitution gave the freedom of peaceful assembly and speech while, on the other, the government issued regulations restricting those rights. Law enforcement did not question the legal status of the new regulations and ignored warnings provided by the media. At the same time, protesters demanded that the police take sides. During anti-government gatherings, they shouted, "come with us". Since these calls fell on deaf ears, they called the officers "traitors" and compared the police with the Citizens' Militia (Milicja Obywatelska), the national police organisation of the Polish People's Republic. In this situation, the police could not make their protest policing style closer to negotiated management due to the lack of willingness of the protesters to negotiate control of the protests. The Covid-19-induced changes in the law enforcement system have meant that the Polish Police have become the government's partisan institution. It forms part of the gradual de-democratisation in Poland. 
Spurned by intense internal conflicts revolving around legal matters, Polish society has become increasingly divided. Both the police and the protesters have relied on a rigid "us" and "them" distinction, although this did not result in mass clashes. The low extent and manner of force indicate that the police did not perceive the protesters as any real threat. The protests were quite peaceful, and acts of violence by their participants were sporadic. Further, the Police management, subordinated to the Ministry of Interior and Administration, did not view the anti-government protests as a threat to the entire system because they were relatively rare, dispersed and fragmented. Consequently, while the revolutionary potential here was negligible given that the protests could hardly affect the government, the risk of them becoming a catalyst for any later wave of protests against police brutality was tremendous.

In sum, this study allowed me to locate the Polish case on five continua whose extreme points are escalated force and negotiated management and to thereby address the research question. The study revealed the model's hybrid nature and orientation towards escalated force. In terms of two dimensions, protection of the right to freedom of peaceful assembly and police tolerance for community disruption, the policing fitted into the pattern of escalated force. In two other dimensions, communication between the police and assembly participants as well as the extent and manner of arrests, the Polish law enforcement approach possesses key features of both models. One dimension, the extent and manner of using force, indicates negotiated management.

\section{BIBLIOGRAPHY}

Bodas-Sagi, Diego J. and José M. Labeaga (2016): Using GDELT Data to Evaluate the Confidence on the Spanish Government Energy Policy. International Journal of Interactive Multimedia and Artificial Intelligence 3 (6): 38-43.

Bowen, Glenn A. (2009): Document Analysis as a Qualitative Research Method. Qualitative Research Journal 9 (2): 27-40.

Daly, Tom G. and Brian C. Jones (2020): Parties versus Democracy: Addressing Today's Political Party Threats to Democratic Rule. International Journal of Constitutional Law 18 (2): 509-538.

Davenport, Christian (2000): Introduction. In Christian Davenport (ed.), Paths to State Repression: Human Rights Violations and Contentious Politics, 1-24. Lanham, MD: Rowman and Littlefield.

della Porta, Donatella (1995): Social Movements and the State: Thoughts on the Policing of Protest. Badia Fiesolana, San Domenico: European University Institute.

della Porta, Donatella (2016): Where Did the Revolution Go? Contentious Politics and the Quality of Democracy. New York: Cambridge University Press. 
della Porta, Donatella and Herbert Reiter (1998): The Policing of Protest in Western Democracies. In Donatella della Porta and Herbert Reiter (eds.), Policing Protest: The Control of Mass Demonstrations in Western Democracies, 1-32. Minneapolis and London: University of Minnesota Press.

della Porta, Donatella and Herbert Reiter (2006): The Policing of Global Protest: The G8 at Genoa and its Aftermath. In Donatella della Porta, Abby Peterson and Herbert Reiter (eds.), The Policing of Transnational Protest, 13-41. Hampshire and Burlington: Ashgate Publishing Limited.

Earl, Jennifer and Sarah A. Soule (2006): Seeing Blue: A Police-Centered Explanation of Protest Policing. Mobilisation: An International Quarterly 11 (2): 145-164.

Earl, Jennifer, Sarah A. Soule and John D. McCarthy (2003): Protest under Fire? Explaining the Policing of Protest. American Sociological Review 68 (4): 581 606.

Fomina, Joanna and Jacek Kucharczyk (2016): The Specter Haunting Europe: Populism and Protest in Poland. Journal of Democracy 27 (4): 58-68.

Hopp, Frederic R., James Schaffer, Jacob T. Fisher and Rene Weber (2019): iCoRe: The GDELT Interface for the Advancement of Communication Research. Computational Communication Research 1 (1): 13-44.

Mansley, David R. (2014): Collective Violence, Democracy and Protest Policing. London and New York: Routledge.

McPhail, Clark and John D. McCarthy (2005): Protests, Protest Repression, and Their Interaction. In Christian Davenport, Hank Johnston and Carol Mueller (eds.), Repression and Mobilisation, 3-32. Minneapolis: University of Minnesota Press.

McPhail, Clark, David Schweingruber and John D. McCarthy (1998): Policing Protest in the United States: 1960-1995. In Donatella della Porta and Herbert Reiter (eds.), Policing Protest: The Control of Mass Demonstrations in Western Democracies, 49-69. Minneapolis and London: University of Minnesota Press.

Rak, Joanna (2018): Theorizing Cultures of Political Violence in Times of Austerity: Studying Social Movements in Comparative Perspective. London, New York: Routledge.

Stott, Clifford and Matthew Radburn (2020): Understanding Crowd Conflict: Social Context, Psychology and Policing. Current Opinion in Psychology 35: 76-80.

Terrill, William (2005): Police Use of Force: A Transactional Approach. Justice Quarterly 22 (1): 107-138.

Walker, Hannah L. (2020): Targeted: The Mobilizing Effect of Perceptions of Unfair Policing Practices. The Journal of Politics 82 (1): 119-134.

Wang, Peng, Paul Joosse and Lok L. Cho (2020): The Evolution of Protest Policing in a Hybrid Regime. The British Journal of Criminology 60 (6): 1523-1546.

Whelan, Chad and Adam Molnar (2019): Policing Political Mega-events through 'Hard' and 'Soft' Tactics: Reflections on Local and Organisational Tensions in Public Order Policing. Policing and Society 29 (1): 85-99.

Wisler, Dominique and Marco Giugni (1999): Under the Spotlight: The Impact of Media Attention on Protest Policing. Mobilisation 4 (2): 171-187. 


\section{SOURCES}

IMM (2020a): Raport IMM: Najbardziej opiniotwórcze media w Polsce. Marzec 2020. Accessible at https://www.imm.com.pl/raport-imm-najbardziej-opiniotworcze-media-w-polsce-marzec-2020/, 16. 4. 2020.

IMM (2020b): Raport IMM: Najbardziej opiniotwórcze media w Polsce. Kwiecień 2020. Accessible at https://www.imm.com.pl/onet-rmf-fm-i-tvn24-liderami-opiniotworczosci-w-kwietniu-2020/, 25. 5. 2020.

IMM (2020c): Raport IMM: Najbardziej opiniotwórcze media w Polsce. Maj 2020. Accessible at https://www.imm.com.pl/najbardziej-opiniotworcze-media-wpolsce-w-maju-2020/, 17. 6. 2020.

Makarewicz, Nicole and Paweł Balinowski (2020): Protest przedsiębiorców. Ponad 380 osób zatrzymanych. Accessible at https://www.rmf24.pl/raporty/raportkoronawirus-z-chin/polska/news-protest-przedsiebiorcow-ponad-380-osobzatrzymanych,nId,4500809, 17. 5. 2020.

Policja (2020a): W związku z obchodami... Accessible at https://twitter.com/policja_ ksp/status/1248533456059011072, 10. 4. 2020.

Policja (2020b): W przypadku nocnego protestu... Accessible at https://twitter.com/ Policja_KSP/status/1258554819289198594, 8. 5. 2020.

Policja (2020c): Informacja o zakazie zgromadzeń... Accessible at https://twitter. com/policja_ksp/status/1243161764650459139, 26. 5. 2020.

Policja (2020d): Stołeczni Policjanci zatrzymali mężczyznę... Accessible at https:// twitter.com/Policja_KSP/status/1260169110664683522, 12.5.2020.

Policja (2020e): Niestety mamy do czynienia... Accessible at https://twitter.com/ policja_ksp/status/1261671884720091136, 22. 5. 2020.

Policja (2020f): W przypadku nocnego protestu... Accessible at https://twitter.com/ Policja_KSP/status/1258554819289198594, 8. 5.2020.

Policja (2020g): Do sądu skierujemy wnioski... Accessible at https://twitter.com/ policja_ksp/status/1243162132394508288, 26. 5. 2020.

Policja (2020h): Informacja o zakazie zgromadzeń... Accessible at https://twitter. com/policja_ksp/status/1243161764650459139, 26. 5. 2020.

Policja (2020i): Jednocześnie przypominamy o obostrzeniach... Accessible at https://twitter.com/policja_ksp/status/1258315329706561541, 7. 5. 2020.

Policja (2020j): Pomimo licznych przekazów dot... Accessible at https://twitter.com/ policja_ksp/status/1264166458545901568, 23. 5. 2020.

Policja (2020k): Działamy transparentnie od początku... Accessible at https://twitter.com/policja_ksp/status/1265989128161759232, 28. 5.2020.

Policja (20201): Kolejne osoby są zatrzymywane... Accessible at https://twitter.com/ policja_ksp/status/1261664363632627712, 16. 5. 2020.

Policja (2020m): Fala hejtu na policjantów... Accessible at https://twitter.com/ policja_ksp/status/1263504291261747201, 21. 5. 2020. 